\title{
Pituitary and testis responsiveness of young male sheep exposed to testosterone excess during fetal development
}

\author{
Mónica P Recabarren, Pedro P Rojas-Garcia, Ralf Einspanier ${ }^{1}$, Vasantha Padmanabhan ${ }^{2}$, \\ Teresa Sir-Petermann ${ }^{3}$ and Sergio E Recabarren \\ Laboratory of Animal Physiology and Endocrinology, Faculty of Veterinary Sciences, Universidad de Concepción, \\ Chillán CP 3812120, Chile, ${ }^{1}$ Institute of Veterinary Biochemistry, Freie Universität Berlin, Berlin, Germany, \\ ${ }^{2}$ Departments of Pediatrics and Reproductive Sciences Program, University of Michigan, Ann Arbor, Michigan 48109, \\ USA and ${ }^{3}$ Laboratory of Endocrinology and Metabolism, Western Faculty of Medicine, Universidad de Chile, \\ Santiago, Chile \\ Correspondence should be addressed to S E Recabarren; Email: srecabar@udec.cl
}

\begin{abstract}
Prenatal exposure to excess testosterone induces reproductive disturbances in both female and male sheep. In females, it alters the hypothalamus-pituitary-ovarian axis. In males, prenatal testosterone excess reduces sperm count and motility. Focusing on males, this study tested whether pituitary LH responsiveness to GNRH is increased in prenatal testosterone-exposed males and whether testicular function is compromised in the testosterone-exposed males. Control males $(n=6)$ and males born to ewes exposed to twice weekly injections of $30 \mathrm{mg}$ testosterone propionate from days 30 to 90 and of $40 \mathrm{mg}$ testosterone propionate from days 90 to 120 of gestation $(n=6)$ were studied at 20 and 30 weeks of age. Pituitary and testicular responsiveness was tested by administering a GNRH analog (leuprolide acetate). To complement the analyses, the mRNA expression of LH receptor (LHR) and that of steroidogenic enzymes were determined in testicular tissue. Basal LH and testosterone concentrations were higher in the testosterone-exposed-males. While LH response to the GNRH analog was higher in the testosterone-exposed males than in the control males, testosterone responses did not differ between the treatment groups. The testosterone:LH ratio was higher in the control males than in the testosterone-exposed males of 30 weeks of age, suggestive of reduced Leydig cell sensitivity to LH in the testosterone-exposed males. The expression of LHR mRNA was lower in the testosterone-exposed males, but the mRNA expression of steroidogenic enzymes did not differ between the groups. These findings indicate that prenatal testosterone excess has opposing effects at the pituitary and testicular levels, namely increased pituitary sensitivity to GNRH at the level of pituitary and decreased sensitivity of the testes to LH.
\end{abstract}

Reproduction (2013) 145 567-576

\section{Introduction}

Evidence is accumulating from both clinical and experimental studies that prenatal exposure to excess testosterone leads to a number of adverse consequences during adult life. In congenital adrenal hyperplasia $(\mathrm{CAH})$, a classic model of prenatal androgen excess in humans, excess androgen production by the fetal adrenal gland leads to androgenization of female fetuses, leading to a series of consequences during postnatal life (Nimkarn et al. 2009). Males with CAH have also been found to manifest perturbations in gametogenesis and metabolic disorders (Cabrera et al. 2001, New 2001, Reisch et al. 2009, Falhammar et al. 2012).

Polycystic ovary syndrome (PCOS), an endocrinemetabolic disorder of high prevalence $(10 \%)$ in women, is characterized by excessive production of androgens. The demonstration some years ago that pregnant PCOS women have higher circulating levels of androgen (Sir-Petermann et al. 2002) raises the possibility that the offspring of these women are likely to be exposed to excess androgen during fetal life. Prospective longitudinal studies to evaluate the effect of prenatal testosterone excess are difficult to perform in humans. Animal models of PCOS (Abbott et al. 1998) are a great resource in this regard. In female sheep exposed prenatally to excess testosterone, multiple neuroendocrine, ovarian, and behavioral disorders are evident from birth to adulthood (Padmanabhan et al. 2006).

Despite the significant advances in understanding the consequences of exposure to excess testosterone during development in females, few studies have addressed the corollary in males. Male offspring of PCOS mothers manifest metabolic disarrangements beginning at birth and culminating in altered lipid profile, insulin resistance and excess weight gain in 
adulthood (Recabarren et al. 2008b). Adult male sheep exposed to excess testosterone manifest a significant reduction in the sperm count, scrotal circumference and sperm motility (Recabarren et al. 2008a), an increased number of Sertoli cells and an altered expression of FSH receptors and TGFB1 and TGFB3 (Rojas-García et al. 2010). To expand our understanding of the developmental consequences of testosterone excess in male sheep, we examined the response of the pituitarygonadal axis following the administration of a GNRH analog, the expression patterns of $\mathrm{LH}$ receptor (LHR) and key steroidogenic enzymes P450c17,20 lyase, $17 \beta$-hydroxysteroid dehydrogenase $(17 \beta-\mathrm{HSD}$ type 3 (17BHSD type 3)), P450 aromatase, P450scc, and $3 \beta-H S D$ (3BHSD) in whole testicular tissue and the expression of P450c17, P450scc, 17BHSD type 3, and 3BHSD in Leydig cells cultured before and after an human chorionic gonadotrophin (hCG) challenge.

\section{Results}

\section{Pituitary $L H$ responsiveness}

20 weeks (prepubertal)

Basal LH levels, mean of six samples immediately before GNRH analog administration, were higher in the testosterone-exposed males $(1.35 \pm 0.53 \mathrm{ng} / \mathrm{ml})$ than in the control males $(0.22 \pm 0.03 \mathrm{ng} / \mathrm{ml})$. GNRH analog administration induced an LH increase in both groups (Fig. 1) with a peak LH response occurring within the first $3 \mathrm{~h}$. The acute and chronic areas under the curves (AUCs) of $\mathrm{LH}$ response in the testosterone-exposed males were twice as high as those in the control males (Fig. 2). Post hoc analyses revealed differences between the treatment groups at 1.5, 2.0, and $2.5 \mathrm{~h}$ after GNRH analog administration (Fig. 1). In the control males, $\mathrm{LH}$ levels returned to basal levels $(\leq 1 \mathrm{ng} / \mathrm{ml}) 18 \mathrm{~h}$ after GNRH analog administration, while the testosterone-exposed males reached basal levels after $42 \mathrm{~h}$ (see inset, Fig. 1).

\section{0 weeks (postpubertal)}

As in prepubertal age, the testosterone-exposed males showed higher basal plasma LH levels than the control males $(0.76 \pm 0.33 \mathrm{ng} / \mathrm{ml}$ in the control males and $2.28 \pm 0.48 \mathrm{ng} / \mathrm{ml}$ in the testosterone-exposed males). Both groups responded to the GNRH analog, although peak LH levels achieved were only half those achieved at 20 weeks of age. Despite this, the testosterone-exposed males had a higher $\mathrm{LH}$ response than the control males, specifically at $1.5,2.0$, and $2.5 \mathrm{~h}$ after GNRH analog administration (Fig. 1). This was reflected as a significant decrease in the AUC of $\mathrm{LH}$ response at this age relative to prepubertal AUC (Fig. 2). The mean acute and chronic AUCs between control males and testosterone-exposed males did not differ at this age. LH levels were below $1 \mathrm{ng} / \mathrm{ml}$ in the control males by $24 \mathrm{~h}$ and in the testosterone-exposed males after $30 \mathrm{~h}$ (see inset, Fig. 1).

\section{Testicular responsiveness}

\section{0 weeks (prepubertal)}

As with $\mathrm{LH}$, basal plasma testosterone concentrations were higher in the testosterone-exposed males $(3.02 \pm$ $1.7 \mathrm{ng} / \mathrm{ml})$ than in the control males $(0.45 \pm 0.27 \mathrm{ng} / \mathrm{ml})$. The time-course of testosterone secretion after GNRH analog administration followed a parallel trajectory to that of LH secretion, with peak concentrations being observed within the first $3 \mathrm{~h}$ of the GNRH analog challenge, that is, during the acute phase. Neither the time-course of testosterone secretion nor testosterone concentrations achieved differed between the treatment groups (Fig. 1). The acute and chronic AUCs of testosterone were consistent with this pattern, with no difference being observed between the groups (Fig. 2).
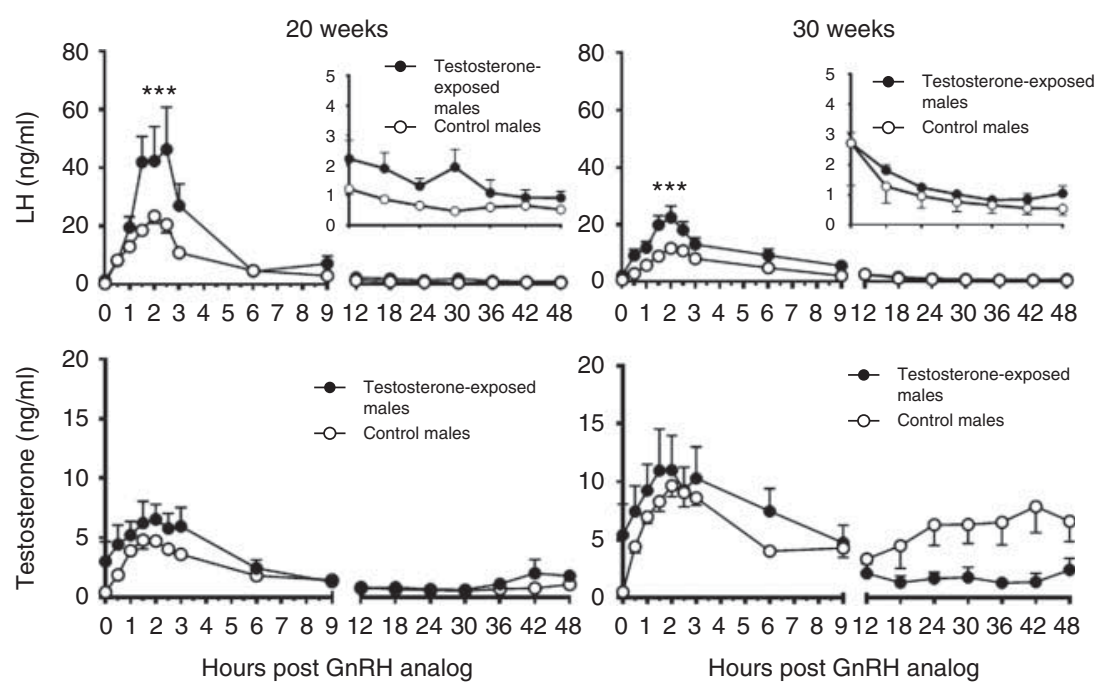

Figure 1 Plasma $\mathrm{LH}$ and testosterone responses to the GNRH analog challenge in the control males (open circles, $n=6$ ) and testosterone-exposed males (filled circles, $n=6$ ) at 20 and 30 weeks of age. Insets in the graphs of $\mathrm{LH}$ show the last $36 \mathrm{~h}$ after GNRH analog administration in $\mathrm{ng} / \mathrm{ml}$. Testosterone-exposed males were born to ewes receiving testosterone propionate from days 30 to 120 of gestation. Asterisks indicate a significant difference between control males and testosteroneexposed males. 

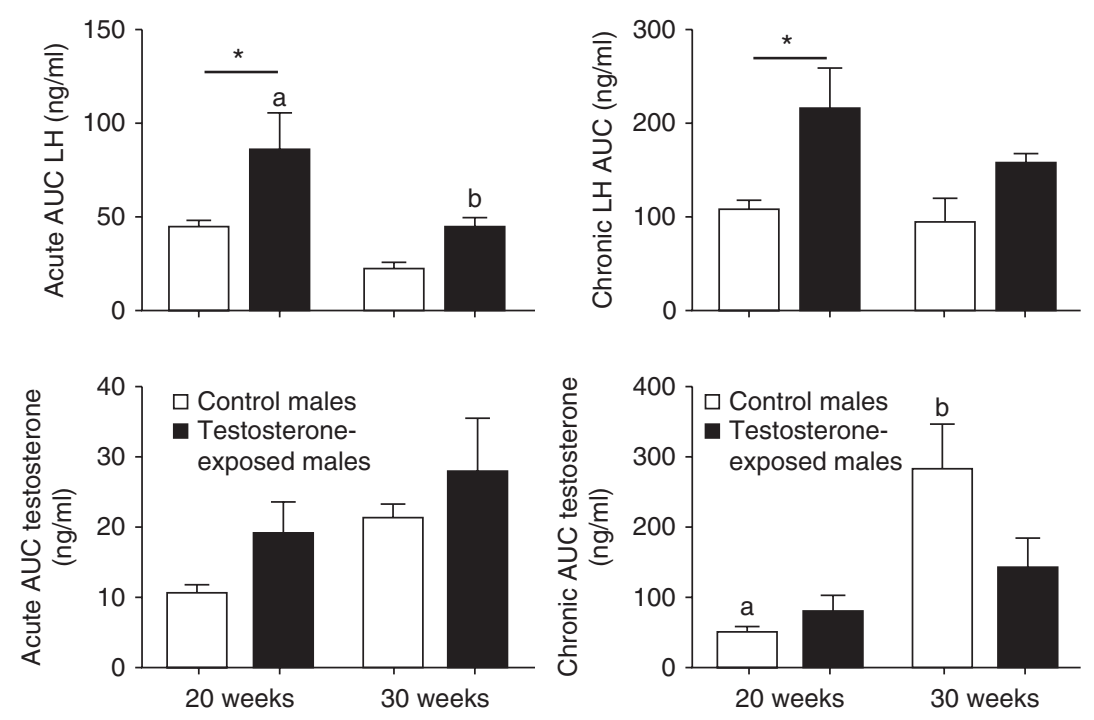

Figure $2 \mathrm{AUC}$ of $\mathrm{LH}$ and testosterone responses following the GNRH analog test during the first $3 \mathrm{~h}$ (acute AUC, top left and bottom left) and during the entire 48-h period (chronic AUC, top right and bottom right) in the control males (white bars) and testosterone-exposed males (black bars). Asterisks indicate significant differences between control males and testosterone-exposed males. A significant age effect within each treatment group is indicated by different letters (a versus b).

\section{0 weeks (postpubertal)}

Basal testosterone levels at this postpubertal age were also higher in the testosterone-exposed males $(6.48 \pm 2.98 \mathrm{ng} / \mathrm{ml})$ than in the control males $(0.53 \pm$ $0.10 \mathrm{ng} / \mathrm{ml}$ ). As was the case at 20 week, plasma testosterone concentration was elevated during the first $3 \mathrm{~h}$ after the GNRH analog challenge (Fig. 1). While there were no differences in the acute release of testosterone between the treatment groups (first $3 \mathrm{~h}$ ), testosterone levels increased during later hours in the control males but not in the testosterone-exposed males (Fig. 2).

\section{Testosterone sensitivity to $\mathrm{LH}$}

The testosterone: $\mathrm{LH}$ ratio serves as an indicator of Leydig cell sensitivity to $\mathrm{LH}$. The testosterone: $\mathrm{LH}$ ratio was similar in the control males and testosterone-exposed males during the first $3 \mathrm{~h}$ of testing at both prepubertal and postpubertal ages. The cumulative testosterone: $\mathrm{LH}$ ratio $(48 \mathrm{~h})$ was significantly lower in the testosterone-exposed males than in the controls at 30 weeks of age. The age-related increase in acute and cumulative testosterone: $\mathrm{LH}$ ratios observed in the controls was not evident in the testosterone-exposed males (Fig. 3).

\section{Testicular gene expression}

Testicular LHR expression was lower in the testosterone-exposed males than in the control males (Fig. 4, $P=0.011$ ). In contrast, the expression levels of P450c17, which is located upstream in the biosynthetic pathway of steroid synthesis converting progesterone to $17-\mathrm{OH}$ progesterone; 17BHSD type 3, whose role is to convert androstenedione to testosterone; and P450 aromatase, which is the last enzyme in this metabolic steroid cascade converting testosterone to estradiol, did not differ between the treatment groups (Fig. 4). There was no correlation between testicular LHR expression and AUC of testosterone in males at 30 weeks of age (Pearson's $r=0.263, P=0.615)$. The mRNA expression of CYP11A1 (P450SCC) and that of CYP17A1 (P450C17) in isolated Leydig cells from the control males and testosterone-exposed males before GNRH analog administration were similar between the treatment groups at each time point studied (Fig. 5). The mRNA expression of $3 B H S D$ and $17 B H S D$ type 3 in Leydig cells was higher after hCG stimulation in both control males and testosterone-exposed males relative to pre hCG levels (Fig. 5). However, there was no significant prenatal testosterone treatment effect.

\section{Discussion}

Findings from the present study show that prenatal testosterone treatment increases pituitary responsiveness to GNRH while decreasing testicular sensitivity. The failure of the testicle to respond to increased $\mathrm{LH}$ release appears to be related to the downregulation of LHR and not changes in steroidogenic enzymes. The mechanisms underlying these functional differences and relevance to male fertility are discussed below.

\section{Impact of prenatal testosterone excess on pituitary $L H$ responsiveness to the $G N R H$ analog challenge}

It is well established that GNRH regulates the synthesis and release of LH (Stanislaus et al. 1998). Recently, we have found that the $\mathrm{LH}$ pulse amplitude of prenatal testosterone- and dihydrotestosterone (DHT)-treated males is increased (Recabarren et al. 2012). In these 

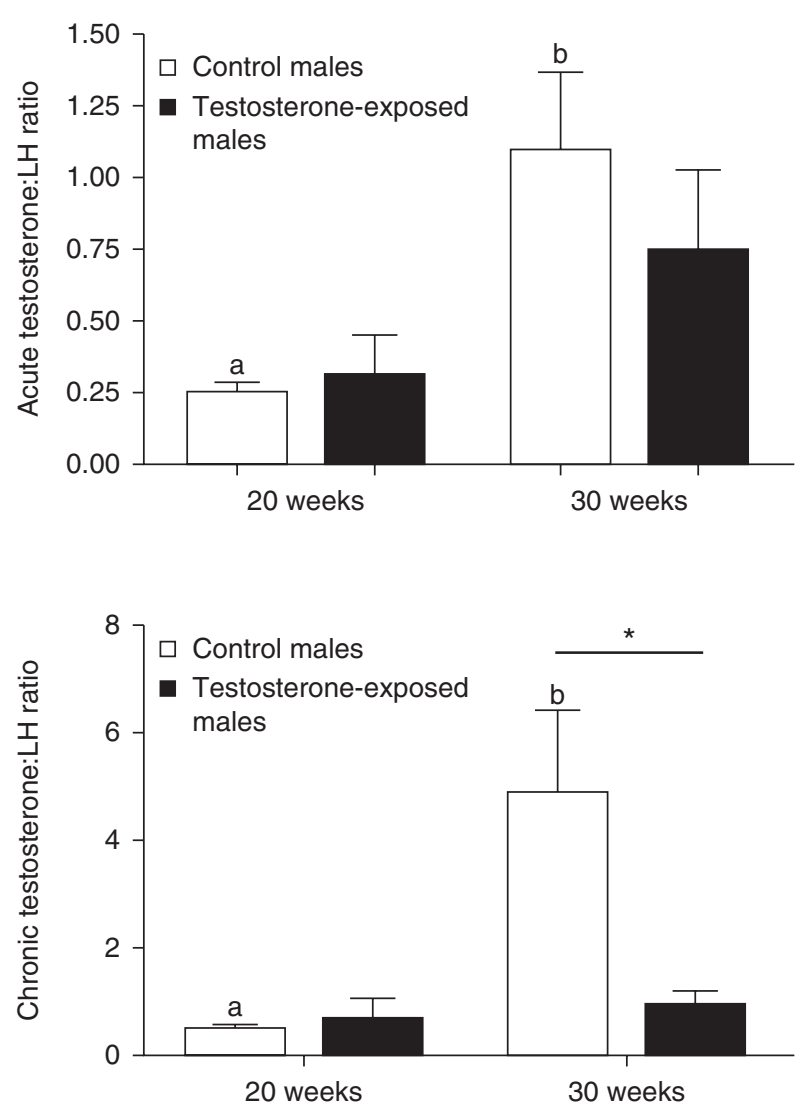

Figure 3 Ratio of testosterone:LH, as an index of gonadal sensitivity. Acute testosterone: $\mathrm{LH}$ ratio during the first $3 \mathrm{~h}$ (left) and chronic testosterone: $\mathrm{LH}$ ratio during the entire 48 -h period (right) in the control males and testosterone-exposed males. A significant (white and black bars respectively) following GNRH analog administration. Asterisk indicates a significant difference between control males and testosterone-exposed males. A significant age effect within each treatment group is indicated by different letters (a versus b).

studies, it was unclear whether the increased LH pulse amplitude of $\mathrm{LH}$ was the result of increased GNRH input or increased pituitary sensitivity to GNRH. Other studies have found that pituitary responsiveness is increased in female offspring born to gestational testosterone-treated animals (Manikkam et al. 2008). Findings of increased $\mathrm{LH}$ release following GNRH analog administration in this study indicate that pituitary responsiveness to GNRH is also increased in the males (this study) as was the case with the females (Manikkam et al. 2008). Together, these findings support a role for increased pituitary responsiveness to GNRH as a contributing factor in the observed increase in the LH pulse amplitude of endogenous $\mathrm{LH}$ pulses of the testosterone-males (Recabarren et al. 2012). Whether the mechanism mediating this increase relates to an increase in $\mathrm{LH}$ synthesis or an increased GNRH receptor expression remains to be investigated. Evidence to date has supported the hypothesis that GNRH has the ability to upregulate its own receptor (Katt et al. 1985, Turzillo et al. 1995a, 1995b, Sakurai et al. 1997) and that the amount of $\mathrm{LH}$ released is a function of the GNRH receptor number (Evans et al. 1997) and LH content (Clarke et al. 1987). It should be recognized that these findings do not exclude any additional contribution stemming from increased GNRH input. Interestingly, a recent study has provided evidence in support of the effect of testosterone at the level of the pituitary. The authors found that pituitary glands of adult prenatal testosterone-treated sheep (both sexes) were 40\% heavier than those of the controls. While no differences in the density of $\mathrm{LH}$ - or ER $\alpha$-immunoreactive cells were found in the pituitary of the control and prenatal testosterone-treated sheep, the percentage of cells co-localizing $\mathrm{LH} \beta$ and $E R \alpha$ was lower in the prenatal testosterone-treated females. This is suggestive of reduced estradiol feedback and consequent hypersecretion of LH (Robinson et al. 2011), a possibility that remains to be explored in the testosterone-exposed males.

The magnitude of response to the GNRH analog at 30 weeks was half of that observed at 20 weeks in both control males and testosterone-exposed males. This probably reflects the negative feedback exerted by testosterone secreted by the maturing testis. With increasing testosterone being produced by the male as it gets older, the pituitary gland gets exposed to higher testosterone negative feedback (Olster \& Foster 1986). Earlier studies of Tilbrook et al. (1991) in rams have shown that the feedback of testosterone is exerted predominantly at the level of the hypothalamus. This could have led to reduced GNRH priming at the pituitary level, consequent reduction in $\mathrm{LH}$ production and release by the pituitary gland.

\section{Effect of prenatal testosterone excess on gonadal testosterone responsiveness to the GNRH analog challenge}

The findings from this study substantiate the role of $\mathrm{LH}$ in stimulating gonadal testosterone response. The $\mathrm{LH}$ response resulting from the GNRH analog challenge was translated into testosterone increase at the gonadal level in both groups of animals. The increase in acute testosterone response at 30 weeks (postpubertal) compared with the response at 20 weeks (prepubertal) in both treatment groups probably reflects the increasing sensitivity of the maturing testis to LH. In male lambs, the response to endogenous $\mathrm{LH}$ increases as they mature (Foster et al. 1978). Paradoxically, the increased LH release that occurred in the testosterone-exposed males following the GNRH analog test was not reflected as an increase in acute testosterone release at both developmental time points. Furthermore, cumulative testosterone secretion over the 48-h test period was reduced in the testosterone-exposed males at 30 weeks than in the control males. Overall, these findings support reduced testicular sensitivity of the exposed males to $\mathrm{LH}$ stimulation. This is substantiated by the fact that the 

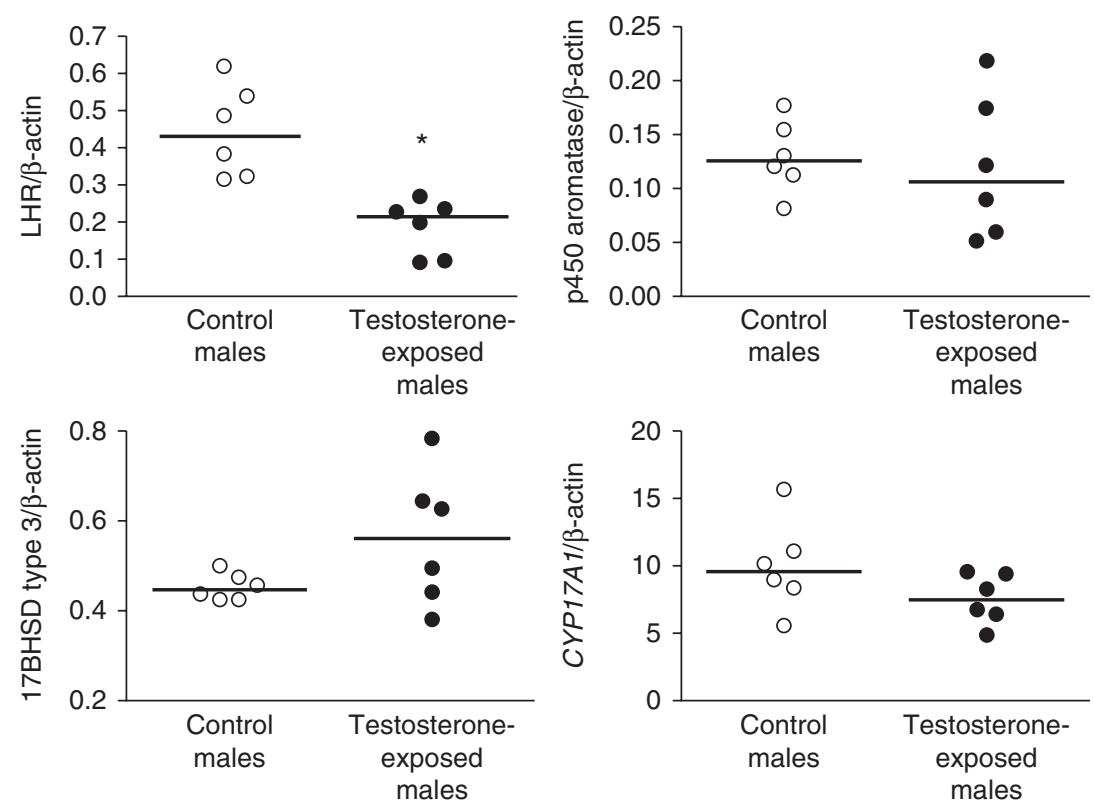

Figure 4 mRNA expression of LHR and steroidogenic enzymes in the testis of the control males (open circles) and testosterone-exposed males (filled circles) at 40 weeks of age. The asterisk indicates significant differences between the groups.

AUC-testosterone-testosterone:AUC-LH ratio was lower in 30-week-old testosterone-exposed males than in the control males.

While testicular responsiveness to the GNRH analog was reduced in prenatal testosterone-treated males, basal testosterone release was high compared with that in the control males. This suggests that prenatal testosteronetreated males may have increased GNRH pulse frequency similar to prenatal testosterone-treated females and thus subject to repetitive pituitary and gonadal stimulation. If so, further stimulation with endogenous $\mathrm{LH}$ released in response to the GNRH stimulus may not lead to increased testosterone production.

There are several explanations for the reduced testosterone response to GNRH analog stimulation. One possibility is that the $\mathrm{LH}$ released in response to $\mathrm{GNRH}$ analog testing may be of qualitatively different nature compared with that released in the controls and not recognized by the RIA. Proper posttranscriptional processing of the LH molecule (Ciccone \& Kaiser 2009) and the resulting polysaccharide moiety is important in conferring biological activity to the $\mathrm{LH}$ molecule (Bergendah \& Veldhuis 2001). Several studies have shown that changes in the mix of $\mathrm{LH}$ isoforms may contribute to differences in the response of the female gonad, but less is known about the response in the Leydig cells of the male gonad (Castro-Fernández et al. 2000, Perera-Marín et al. 2007, Olivares et al. 2009). In a rat model of diet-induced obesity, LH bioactivity was reduced, rendering the male hypogonadal (Olivares et al. 2010). More acidic forms are predominant in eugonadal men (Bergendah \& Veldhuis 2001). The altered pattern of endogenous GNRH release (assessed from LH pulsatility) during post-development trajectory
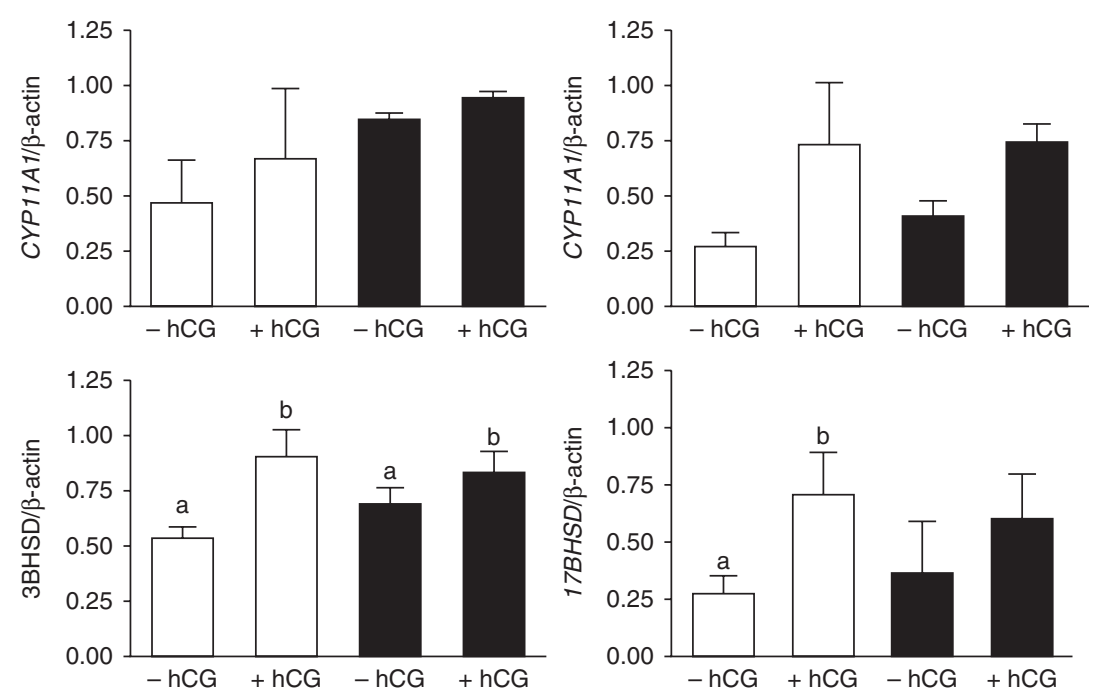

Figure 5 mRNA expression of steroidogenic enzymes in Leydig cells from the control males (white bars) and testosterone-exposed males (black bars) without hCG stimulation (-hCG) and $24 \mathrm{~h}$ after stimulation with hCG (+hCG). Significant difference within groups before and after hCG stimulation is shown by different letters (a versus b). 
in the testosterone-exposed males (Recabarren et al. 2012) may have contributed to the production of less acidic fast-clearing $\mathrm{LH}$ that does not provide sustained support in the testosterone-exposed males as in the control males. This premise is consistent with our earlier finding that hCG stimulation of the control males and testosterone-exposed males elicits similar testosterone responses at 40 weeks of age (Recabarren et al. 2008a).

Reduced expression of LHR mRNA of the testosterone-exposed males compared with the expression in the control males may be responsible for the reduced testicular response. However, diminished LHR mRNA expression did not correlate with the AUC of testosterone response to GNRH analog testing. Whether LHR protein changes correlate with testosterone response remains to be determined. The lack of difference in the mRNA levels of key steroidogenic enzymes indicates that the decreased cumulative testosterone response of the testosterone-exposed males may not be the function of steroidogenic enzymes being limiting. Furthermore, although $3 B H S D$ and $17 B H S D$ type 3 mRNA expression in Leydig cells in a suspension culture increased in response to hCG stimulation, there was no prenatal treatment effect, confirming observations in testicular mRNA expression. These findings at the level of mRNA need to be interpreted with caution since changes may have occurred at the protein level.

These findings provide evidence that exposure to excess testosterone during fetal development not only disrupts testicular differentiation, leading to a reduced number of sperm cells and compromised Sertoli cell function (Recabarren et al. 2008a, 2008b, Rojas-García et al. 2010, 2013), but also disrupts the interface of the pituitary-gonadal axis. How these findings are enchained remains to be investigated.

While we did not analyze spermatogenesis in this study, we have investigated this extensively in previous studies. These studies showed no differences between control males and testosterone-exposed males (RojasGarcía et al. 2013) at 4 weeks of age. In contrast, spermatogenesis was found to be impaired with a lower number of spermatogonia, spermatocytes I, and spermatides per tubule in adult prenatal testosterone-treated males (Rojas-García et al. 2010).

Considering that adult reproductive function is the culmination of proper developmental ontogeny of the hypothalamo-pituitary-gonad axis, any perturbation in this developmental sequence would lead to perturbation in fertility. In the present study, a derangement was observed in the relationship between the pituitary gland and the testicle in peripubertal males because of the prenatal exposure to testosterone. This could jeopardize the future fertility of the testosterone-exposed. Since excess of testosterone may be seen as an endocrine disruptor as well as an environmental disruptor (Skakkebaek et al. 2001), these findings in our animal model could, although with caution, be extended to human reproductive health, in particular, to sons of pregnant PCOS women. In support of this premise, placentas from PCOS mothers were found to have lower aromatase and higher 3 3 -HSD1 activities, which could lead to increased androgen levels during pregnancy (Maliqueo et al. 2013). The studies of Veiga-Lopez et al. (2011) in sheep have found male and female sheep fetuses whose mothers were administered testosterone to have elevated plasma testosterone levels compared with their control counterparts.

\section{Materials and Methods \\ General management, breeding, and prenatal testosterone exposure}

This study began in late March/early April during the natural breeding season at the Chillán Campus of the University of Concepcion, Chile $\left(36^{\circ} 36^{\prime}\right.$ south latitude, $71^{\circ} 30^{\prime}$ west longitude, $144 \mathrm{~m}$ above the sea level). Adult Suffolk Down females were mated as described previously (Recabarren et al. 2008a). After synchronization of estrous and controlled mating, pregnant sheep were allocated randomly to one of two treatments. One group of pregnant sheep received twice weekly i.m. injections of $30 \mathrm{mg}$ testosterone propionate (T; Steraloids, Newport, RI, USA) dissolved in cottonseed oil as a vehicle, between 30 and 90 days of pregnancy, followed by injections of $40 \mathrm{mg}$ testosterone from days 90 to 120 of pregnancy. Another group served as a control and received an oil vehicle twice weekly from days 30 to 120 of gestation. This regimen of testosterone administration was chosen to reflect the higher levels of testosterone observed in women with PCOS during their pregnancies and has been used in previous studies (Sir-Petermann et al. 2002, Recabarren et al. 2008a).

Ewes were maintained on pasture and supplemented with pellet food to meet the energy requirements of pregnant sheep. Lambs were born in mid-September by normal delivery, after full-length gestation (mean of 147 days), and were weaned at 8 weeks of age. They were maintained under natural photoperiod and given free access to water and pasture and supplemented twice a day with hay and commercial pelleted food for ruminants as detailed elsewhere (Recabarren et al. 2008a). Only males born from singleton pregnancies were used in this study. All management and experimental methodologies were approved by the Ethical Committee in Animal Research of the Faculty of Veterinary Sciences of the University of Concepción.

\section{Pituitary/gonadal responsiveness}

GNRH analog testing for assessing pituitary and gonadal responsiveness was undertaken with the control males $(n=6$, born to ewes receiving the vehicle) and testosterone-exposed males $(n=6$, born to ewes receiving testosterone during pregnancy) at 20 and 30 weeks of age. These ages were chosen because they encompass the peripubertal window with, 20 weeks representing the prepubertal period and 30 weeks the postpubertal period of sexual development. Puberty is defined as the age at which the presence of sperm 
cells in the ejaculate is first observed. In an earlier study, we found first sperm cells appearing in the ejaculate at 26 weeks of age with a steady presence of sperm cells being evident at 30 weeks of age (Recabarren et al. 2008a). A similar definition for puberty in male sheep has been employed by other investigators (Olster \& Foster 1986, Wheaton et al. 2003), except that in Olster \& Foster (1986)'s study, the presence of sperm cells was observed at 16-18 weeks of age, while in our flock, this was observed at 26 weeks of age. This difference may be related to the body conditions of lambs.

One or two days before GNRH analog testing, indwelling catheters were placed in both jugular veins under local anesthesia as described previously (Recabarren et al. 1995). Blood sampling was performed to acclimatize the males to the procedures and to review the patency of the catheters. On the day of the experiment, males were placed in experimental crates. Pasture and water were available at all time points. All studies began at $1400 \mathrm{~h}$ local time.

GNRH analog testing involved the administration of leuprolide acetate (Lupron Abbott, $10 \mu \mathrm{g} / \mathrm{kg}$ body weight) via one of the indwelling catheters and collection of blood samples through the second catheter at $0,0.5,1,1.5,2.0,2.5$, and $3 \mathrm{~h}$ for determining the acute $\mathrm{LH}$ and testosterone responses and at 6, 9, 12, 18, 24, 30, 36, 42, and $48 \mathrm{~h}$ for assessing the long-lasting effect of the GNRH analog on the $\mathrm{LH}$ and testosterone release. Blood $(2 \mathrm{ml})$ was collected in tubes containing $10 \mu \mathrm{l}$ of heparin $(10 \mathrm{U} / \mu \mathrm{l})$ and centrifuged at $1000 \mathrm{~g}$ for $4 \mathrm{~min}$ at $4{ }^{\circ} \mathrm{C}$ degrees and plasma was harvested. Plasma samples were stored at $-20{ }^{\circ} \mathrm{C}$ degrees until later $\mathrm{RIA}$ for $\mathrm{LH}$ and testosterone.

\section{Testicular gene expression studies}

To avoid transient changes stemming from GNRH analog testing in testicular gene expression, these studies were undertaken at 40 weeks of age. The left testicle was removed from each male for RNA isolation. In brief, rams were anesthetized with halothane, and their testicles were surgically removed and cut into small pieces of $0.5 \mathrm{~cm}^{3}$ in size. Some of these pieces were left immersed in RNAlater (Ambion, Carlsbad, CA, USA) and stored at $-20^{\circ} \mathrm{C}$ for total RNA isolation. Other pieces were also used for the in vitro culture of Leydig cells.

For RNA isolation, testicular tissue was homogenized using Lysing Matrix D (MP) and the FastPrep instrument (FP120, Bio 101; Thermo Electron, Osterode, Germany) and total RNA was isolated using the RNeasy Mini Kit (Qiagen) as per the manufacturer's instructions. The yield of total RNA was quantified photometrically at $260 \mathrm{~nm}$ using the Nanodrop 1000 spectrophotometer (Thermo Scientific, Schweter, Germany). The quality of the RNA samples was assessed after electrophoresis on formaldehyde containing 1\% (wt/vol) agarose gel with ethidium bromide staining. The quality of the RNA samples with a low RNA concentration was further verified using the Agilent 2100 Bioanalyzer and the RNA Nano Chips (Agilent, Waldbronn, Germany). To eliminate DNA contamination, the samples were subjected to DNase treatment prior to RT. A $1 \mu$ l sample of total RNA was incubated with $1 \mathrm{U}$ DNase (Promega) in a total volume of $20 \mu \mathrm{l}$ of $1 \times$ buffer used in the RT at $37{ }^{\circ} \mathrm{C}$ for $30 \mathrm{~min}$, heated at $75^{\circ} \mathrm{C}$ for $5 \mathrm{~min}$ to inactivate the DNase, and then placed immediately on ice for $5 \mathrm{~min}$. A $40 \mu \mathrm{l}$ volume of a premix containing $200 \mathrm{U}$ Moloneymurine leukemia virus reverse transcriptase (M-MLV RT; Promega), $2.5 \mu \mathrm{M}$ of random hexamers (Amersham Biosciences), $0.666 \mathrm{mM}$ of each dNTP (Amersham Biosciences), and $1 \mathrm{X}$ of the supplied RT buffer were added to each RNA sample. Samples without the M-MLV enzyme were run at the same time to monitor the absence of any genomic DNA. RT was performed at $25^{\circ} \mathrm{C}$ for $10 \mathrm{~min}$ and at $42{ }^{\circ} \mathrm{C}$ for $1 \mathrm{~h}$ and then at $90{ }^{\circ} \mathrm{C}$ for $2 \mathrm{~min}$. The cDNA was aliquoted in $20 \mu \mathrm{l}$ volumes $(16 \mathrm{ng} / \mu \mathrm{l} \mathrm{CDNA})$ and stored at $-20{ }^{\circ} \mathrm{C}$ until analysis by real-time PCR.

\section{Real-time PCR}

In preliminary experiments, the expression of all genes was examined by standard gradient PCR using a gradient thermocycler (Mastercycler gradient; Eppendorf, Hamburg, Germany) to confirm the expected amplicon sizes as well as to estimate the optimal annealing temperature for each pair of primers. Real-time PCRs were performed in a Rotor-Gene RG-3000 thermocycler (Corbett Research, Mortlake, NSW, Australia).

Table 1 Sequence for primers used in the real-time PCR.

\begin{tabular}{|c|c|c|c|c|}
\hline Genes & Primers & $\begin{array}{c}\text { Annealing } \\
\left({ }^{\circ} \mathrm{C}\right)\end{array}$ & $\begin{array}{l}\text { PCR product } \\
\text { length }(\mathrm{bp})\end{array}$ & References \\
\hline$\beta$-Actin & $\begin{array}{l}\text { F: } 5^{\prime} \text {-CTC TTC CAG CCT TCC TTC CT-3' } \\
\text { R: } 5^{\prime} \text {-GGG CAG TGA TCT CTT TCT GC-3' }\end{array}$ & 55 & 178 & Rojas-García et al. (2010) \\
\hline LHR & $\begin{array}{l}\text { F: } 5^{\prime} \text {-GAT AGA AGC TAA TGC CCT TGA CAA C-3' } \\
\text { R: } 5^{\prime} \text {-CCA GAA TGA AAT TAA ATT CAG AGG AG-3' }\end{array}$ & 60 & 197 & GenBank accession no. L36329 \\
\hline P450c17,20 & $\begin{array}{l}\text { F: } 5^{\prime} \text {-TGG CGG TCA CCA ACA TAA TC-3' } \\
\text { R: } 5^{\prime} \text {-CAT TCA CCT TGG CTT GCA TC- } 3^{\prime}\end{array}$ & 60 & 300 & GenBank accession no. AF251388 \\
\hline P450 aromatase & $\begin{array}{l}\text { F: 5'-TCG TGG TTA AAA TCC AGG GG-3' } \\
\text { R: 5'-TCA TTG CCT CTT CAA CCT GG-3' }\end{array}$ & 60 & 341 & GenBank accession no. AJ012153 \\
\hline CYP11A1 & $\begin{array}{l}\text { F: 5'-AGAGAATCCACTTTCGCCACATC-3' } \\
\text { R: 5'-GGTCTTTCTTCCAGGTTCCTGAC-3' }\end{array}$ & 55 & 237 & Vanselow et al. (2004) \\
\hline $3 B H S D$ & $\begin{array}{l}\text { F: 5'-TGTTGGTGGAGGAGAAGGATCTG-3' } \\
\text { R: 5'-TGGGTACCTTTCACATTGACGTTC-3' }\end{array}$ & 57 & 253 & Vanselow et al. (2004) \\
\hline $17 B H S D$ type 3 & $\begin{array}{l}\text { F: 5'-TGG GAG AAT GGG CAG TGA TC-3' } \\
\text { R: 5'-TGT TAA GGA AAT GGC TTG GG-3' }\end{array}$ & 60 & 297 & $\begin{array}{l}\text { GenBank accession no. } \\
\text { NM_001076439 }\end{array}$ \\
\hline
\end{tabular}

$F$, forward; $R$, reverse. 
The primer sequences, annealing temperature, and length of the PCR products used in the present study are given in Table 1.

A $1 \mu \mathrm{l}$ volume of cDNA (16 ng) was used as a template for real-time PCR containing $0.2 \mu \mathrm{l}$ of $50 \times$ SYBR Green and $5 \mu \mathrm{l}$ of $2 \times$ SensiMix solution (Quantace, London, UK) and $0.4 \mu \mathrm{M}$ of each primer in a final volume of $10 \mu \mathrm{l}$. The following real-time PCR protocol was applied: a denaturation step at $95{ }^{\circ} \mathrm{C}$ for $10 \mathrm{~min}$; a three-step amplification including denaturation at $95{ }^{\circ} \mathrm{C}$ for $15 \mathrm{~s}$, the corresponding annealing temperature specific for each gene (see below) for $20 \mathrm{~s}$, and extension at $72{ }^{\circ} \mathrm{C}$ for $30 \mathrm{~s}$; a melting curve program $\left(50-99{ }^{\circ} \mathrm{C}\right)$ with continuous fluorescence measurement; and a final cooling step to $40{ }^{\circ} \mathrm{C}$. Data acquisition was carried out at the end of each annealing and extension step. The number of cycles for all factors was 45. For mRNA quantification, a dilution series with known quantities of the specific PCR product was amplified simultaneously with the samples as a standard. Samples were measured in triplicates and the standard curves in duplicates in the same run. The PCR products applied as standards were generated by conventional block RT-PCR and purified using the Invisorb Spin DNA Extraction Kit (Invitek, Berlin, Germany) as described by the manufacturer. The concentration of the purified PCR products was estimated in duplicates using the Nanodrop 1000 spectrophotometer.

The melting points of the amplified products served as confirmation of specific amplification. As negative controls, reactions containing no template (sterile RNase-DNase-free water) or no reverse transcriptase were included to exclude any PCR products derived from contaminations or from genomic DNA. The content of each specific mRNA was normalized to a housekeeping gene. In previous steps during this study, the gene expression of the $18 \mathrm{~S}$ ribosomal subunit and $\beta$-actin was tested to choose the suitable and reliable housekeeping gene as an internal control for the normalization of the genes under study. The expression of $\beta$-actin resulted in a similar level between control males and testosterone-exposed males. Therefore, we chose to use $\beta$-actin as the internal control. The data from real-time PCR are presented as a ratio of the specific mRNA gene to $\beta$-actin expression.

\section{Leydig cell gene responsiveness to $h C G$}

Leydig cells were isolated from six testosterone-exposed males and three control males and subjected to an hCG (Chorulon, Intervet, Chile) challenge. Approximately $50 \mathrm{~g}$ of testis tissue were subjected to enzymatic dispersion with $0.25 \mathrm{mg} / \mathrm{ml}$ of collagenase (type I, Gibco) at $37^{\circ} \mathrm{C}$ for $15 \mathrm{~min}$ in a shaking bath to isolate interstitial cells. Interstitial cells were then filtered through gauze to remove fragments of seminiferous tubules. Leydig cells were purified from the crude interstitial fraction on a discontinuous gradient of Percoll prepared in HEPES buffer, pH 7.4, as described by Anakwe et al. (1985). Briefly, $20 \mathrm{ml}$ of a $90 \%$ Percoll (Sigma) solution were layered under $20 \mathrm{ml}$ of a $40 \%$ Percoll solution in a $50 \mathrm{ml}$ conical tube. Interstitial cells were layered on top of the gradient in M199 and centrifuged for $15 \mathrm{~min}$ at $800 \mathrm{~g}$. The Leydig cell fraction at the interface of the two Percoll solutions was aspirated off, diluted with M199, and collected by centrifugation at $600 \mathrm{~g}$ for $10 \mathrm{~min}$. The cell pellet was resuspended; the process was repeated until no cell aggregates were visible. The isolated Leydig cells were collected by centrifugation, washed two times with M199, and then suspended in $5 \mathrm{ml} \mathrm{M199.} \mathrm{Leydig}$ cell number was established using a hemocytometer and cell viability was assessed by Trypan Blue exclusion. Leydig cell purity was confirmed by a histochemical reaction for 3BHSD and immunocytochemistry for P450c17 enzyme using a polyclonal rabbit anti-bovine antibody (Peterson et al. 2001) donated by Dr Alan J Conley (University of California School of Veterinary Medicine, Davis, USA).

Purified Leydig cells $\left(1 \times 10^{6}\right)$ were maintained in a suspension culture at $34{ }^{\circ} \mathrm{C}$ under $5 \% \mathrm{CO}_{2}-95 \%$ air for $12 \mathrm{~h}$. Cell suspensions were washed and then incubated with or without $1 \mathrm{IU} / \mathrm{ml}$ of hCG for $24 \mathrm{~h}$ (Cheng et al. 2003). Leydig cells were then washed twice with PBS. For total RNA isolation, cells were lysed using the RNA extraction kit (Invitek) according to the manufacturer's instructions. All procedures were performed in duplicates. For the determination of RNA yield and its quality, DNase treatment (carried out in a $5 \mu \mathrm{l}$ volume), RT, and real-time PCR were carried out using the procedures described above. RT was performed with $250 \mathrm{ng}$ of total RNA in a final volume of $20 \mu \mathrm{l}$.

\section{Hormone measurements}

Plasma LH concentrations were determined by RIA using ovine radio-iodinated LH (LER 1374-A, provided by Dr Leo E Reichert, Jr), ovine antiserum CSU-204 (provided by Dr Gordon Niswender), and ovine LH standard oLH-S25 (provided by NIADDK, Bethesda, MA, USA) in $200 \mu \mathrm{l}$ duplicates, following the previously described procedures (Recabarren et al. 1996). The minimal detectable LH dose, defined as $90 \%$ of the buffer control, was $0.1 \mathrm{ng} / \mathrm{ml}$ and the intra- and interassay coefficients of variation ( $\mathrm{CVs}$ ) were 5 and $12 \%$ respectively. Plasma testosterone concentrations were determined by RIA using commercial kits validated for ovine plasma (DSL, Webster, TX, USA). The minimal detectable limit of testosterone assay corresponding to $90 \%$ of the buffer control was $0.05 \mathrm{ng} / \mathrm{ml}$ and the intra- and interassay CVs were 3 and $7 \%$ respectively.

\section{Statistical analysis}

Results from the GNRH analog test at each age were analyzed by ANOVA for repeated measures and comparisons of the means with the Newman-Keuls test using the GB Stat v.5 program. $\mathrm{LH}$ and testosterone responses during the first $3 \mathrm{~h}$ of the test and during the entire experiment $(48 \mathrm{~h})$ were converted to AUC using the trapezoidal formula. These data were analyzed by ANOVA for repeated measures with treatment (control versus testosterone) as the main factor and age (20 and 30 weeks of age) as the repeated-measures factor, using the GB Stat version 6.5 statistical program. Pairwise post hoc comparisons were made with the Dunnnet test using the GB Stat v.5 program.

Pearson's correlation was made between total AUC of testosterone in males of 30 weeks of age and LHR mRNA expression to characterize the association between both variables. 
The expression level of mRNA is given in relation to the expression level of the housekeeping gene $\beta$-actin. The data were analyzed using unpaired Student's t-test or the MannWhitney $U$ nonparametric test and a two-way ANOVA, whenever necessary, using the GraphPad Prism 4.0 Software (GraphPad, San Diego, CA, USA). For all tests, $P<0.05$ was considered statistically significant. Data are given as mean or median \pm S.E.M. or S.D. as indicated in the figures.

\section{Declaration of interest}

The authors declare that there is no conflict of interest that could be perceived as prejudicing the impartiality of the research reported.

\section{Funding}

This work was supported by Fondecyt grants 1050915 and 1090031. The participation of Dr Vasantha Padmanabhan in this work was in the frame of the Fondecyt International Cooperation Project 1090031. The participation of Dr Ralf Einspanier and Dr Pedro P Rojas-García was supported by DGF 444CHL 113/7/0-1.

\section{Acknowledgements}

We are grateful to Drs G D Niswender, L E Reichert Jr, and A F Parlow for providing reagents for the ovine LH RIA; Dr José Cox for the use of his laboratory facilities to surgically collect the testis; Drs Jenny Schön and Christopher Gabler (Department of Veterinary Biochemestry, Frei Universität Berlin, Germany) for their advice in the RT-PCR; Dr Ana Maria Ronco for her advice in Leydig cell culture; and the Deutscher Akademischer Austausch Dienst (DAAD) for the donation of the Biophotometer. Part of this work was presented at Endo 2010, June 19-22, San Diego, USA.

\section{References}

Abbott DH, Dumesic DA, Eisner JR, Colman RJ \& Kemnitz JW 1998 Insights into the development of polycystic ovary syndrome (PCOS) from studies of prenatally androgenized female rhesus monkeys. Trends in Endocrinology and Metabolism 9 62-67. (doi:10.1016/S1043-2760 (98)00019-8)

Anakwe OO, Murphy PR \& Moger WH 1985 Characterization of $\beta$-adrenergic binding sites on rodent Leydig cells. Biology of Reproduction 33 815-826. (doi:10.1095/biolreprod33.4.815)

Bergendah M \& Veldhuis JD 2001 is there a physiological role for gonadotrophin oligosaccharide heterogeneity in humans? III. Luteinizing hormone heterogeneity: a medical physiologist's perspective Human Reproduction 16 1058-1064. (doi:10.1093/humrep/16.6.1058)

Cabrera MS, Vogiatzi MG \& New MI 2001 Long term outcome in adult males with classic congenital adrenal hyperplasia. Journal of Clinical Endocrinology and Metabolism 86 3070-3078. (doi:10.1210/jc.86.7. 3070)

Castro-Fernández C, Olivares A, Söderlund D, López-Alvarenga JC, Zambrano E, Veldhuis JD, Ulloa-Aguirre A \& Méndez JP 2000 A preponderance of circulating basic isoforms is associated with decreased plasma half-life and biological to immunological ratio of gonadotropinreleasing hormone-releasable luteinizing hormone in obese men. Journal of Clinical Endocrinology and Metabolism 85 4603-4610. (doi:10.1210/jc.85.12.4603)
Cheng J, Fu J-L \& Zhou Z-C 2003 The inhibitory effects of manganese on steroidogenesis in rat primary Leydig cells by disrupting steroidogenic acute regulatory (StAR) protein expression. Toxicology 187 139-148. (doi:10.1016/S0300-483X(03)00063-5)

Ciccone NA \& Kaiser UB 2009 The biology of gonadotroph regulation. Current Opinion in Endocrinology, Diabetes, and Obesity 16 321-327. (doi:10.1097/MED.0b013e32832d88fb)

Clarke IJ, Cummins JT, Crowder ME \& Nett TM 1987 Pituitary receptors for gonadotropin-releasing hormone in relation to changes in pituitary and plasma luteinizing hormone in ovariectomized-hypothalamus disconnected ewes. I. Effect of changing frequency of gonadotropin-releasing hormone pulses. Biology of Reproduction 37 749-754. (doi:10.1095/ biolreprod37.4.749)

Evans NP, Bramley TA, McNeilly JR \& Webb R 1997 Extra- and intracellular effects of divergent selection for pituitary responsiveness to gonadotropin-releasing hormone in prepubertal ram lambs. Biology of Reproduction 57 128-133. (doi:10.1095/biolreprod57.1.128)

Falhammar H, Nyström HF, Ekström U, Granberg S, Wedell A \& Thorén M 2012 Fertility, sexuality and testicular adrenal rest tumors in adult males with congenital adrenal hyperplasia. European Journal of Endocrinology 166 441-449. (doi:10.1530/EJE-11-0828)

Foster DL, Mickelson IH, Ryan KD, Coon RGA, Drongowski RA \& Holt JD 1978 Ontogeny of pulsatile luteinizing hormone and testosterone in male lambs. Endocrinology 102 1137-1146. (doi:10.1210/endo-102-4-1137)

Katt JA, Duncan JA, Herbon L, Barkan A \& Marshall JC 1985 The frequency of gonadotropin-releasing hormone stimulation determines the number of pituitary gonadotropin-releasing hormone receptors. Endocrinology 116 2113-2115. (doi:10.1210/endo-116-5-2113)

Maliqueo M, Lara HE, Sánchez F, Echiburú B, Crisosto N \& Sir-Petermann T 2013 Placental steroidogenesis in pregnant women with polycystic ovary syndrome. European Journal of Obstetrics, Gynecology, and Reproductive Biology 166 151-155. (doi:10.1016/j.ejogrb.2012.10.015)

Manikkam M, Thompson RC, Herkimer C, Welch KB, Flak J, Karsch FJ \& Padmanabhan V 2008 Developmental programming: impact of prenatal testosterone excess on pre- and postnatal gonadotropin regulation in sheep. Biology of Reproduction 78 648-660. (doi:10.1095/biolreprod. 107.063347)

New MI 2001 Factors determining final height in congenital adrenal hyperplasia. Journal of Pediatric Endocrinology \& Metabolism 14 (Suppl 2) 933-937.

Nimkarn S, Lin-Su K \& New MI 2009 Steroid 21 hydroxylase deficiency congenital adrenal hyperplasia. Endocrinology and Metabolism Clinics of North America 38 699-718. (doi:10.1016/j.ecl.2009.08.001)

Olivares A, Méndez JP, Cárdenas M, Oviedo N, Palomino MA, Santos I, Perera-Marín G, Gutiérrez-Sagal R \& Ulloa-Aguirre A 2009 Pituitarytesticular axis function, biological to immunological ratio and charge isoform distribution of pituitary LH in male rats with experimental diabetes. General and Comparative Endocrinology 161 304-312. (doi:10.1016/j.ygcen.2008.12.021)

Olivares A, Méndez JP, Zambrano E, Cárdenas M, Tovar A, Perera-Marín G \& Ulloa-Aguirre A 2010 Reproductive axis function and gonadotropin microheterogeneity in a male rat model of diet-induced obesity. General and Comparative Endocrinology 166 356-364. (doi:10.1016/j.ygcen. 2009.12.007)

Olster DH \& Foster DL 1986 Control of gonadotropin secretion in the male during puberty: a decrease in response to steroid inhibitory feedback in absence of an increase steroid independent drive in the sheep. Endocrinology 118 2225-2234. (doi:10.1210/endo-118-6-2225)

Padmanabhan V, Manikkam M, Recabarren S \& Foster D 2006 Prenatal testosterone excess programs reproductive and metabolic dysfunction in the female. Molecular and Cellular Endocrinology 246 165-174. (doi:10.1016/j.mce.2005.11.016)

Perera-Marín G, Murcia C \& González-Padilla C 2007 Luteinizing hormone (LH) isoforms in ruminants: characterization and physiological relevance. Animal Reproduction Science 101 187-207. (doi:10.1016/j. anireprosci.2007.03.011)

Peterson JK, Moran F, Conley AJ \& Bird IM 2001 Zonal expression of endothelial nitric oxide synthase in sheep and rhesus adrenal cortex. Endocrinology 142 5351-5363. (doi:10.1210/en.142.12.5351)

Recabarren SE, Urrucelqui A, Robbiano M, Lobos A, Orellana P \& Parilo J 1995 Effect of arginine and ornithine infusions on secretion of the growth hormone in prepubertal ewes. Archivos deMedicina Veterinaria 27 99-104. 
Recabarren SE, Escobar A, Lobos A, Recabarren MP \& Parilo J 1996 Luteinizing hormone pulse frequency is increased by arginine infusion in prepubertal sheep. Experimental and Clinical Endocrinology and Diabetes 104 74-79. (doi:10.1055/s-0029-1211425)

Recabarren SE, Rojas-García PP, Recabarren MP, Alfaro VH, Smith R, Padmanabhan V \& Sir-Petermann T 2008a Prenatal testosterone excess reduces sperm count and motility. Endocrinology 149 6444-6448. (doi:10.1210/en.2008-0785)

Recabarren SE, Smith R, Rios R, Maliqueo M, Echiburú B, Codner E, Cassorla F, Rojas P \& Sir-Petermann T 2008b Metabolic profile in sons of women with polycystic ovary syndrome. Journal of Clinical Endocrinology and Metabolism 93 1820-1826. (doi:10.1210/jc. 2007-2256)

Recabarren SE, Recabarren M, Rojas-García PP, Cordero M, Reyes C \& Sir-Petermann T 2012 Prenatal exposure to androgen excess increases LH pulse amplitude during postnatal life in male sheep. Hormone and Metabolic Research 44 688-693. (doi:10.1055/ s-0032-1316291)

Reisch N, Flade L, Scherr $M$, Rottenkolber $M$, Pedrosa Gil F, Bidlingmaier M, Wolff H, Schwarz HP, Quinkler M, Beuschlein F et al. 2009 High prevalence of reduced fecundity in men with Congenital Adrenal Hyperplasia. Journal of Clinical Endocrinology and Metabolism 94 1665-1670. (doi:10.1210/jc.2008-1414)

Robinson J, Hastie P, Shah A, Smith A \& Evans N 2011 Developmental programming: prenatal androgen exposure alters the gonadotroph population of the ovine pituitary gland. Journal of Neuroendocrinology 24 434-442. (doi:10.1111/j.1365-2826.2011.02264.x)

Rojas-García PP, Recabarren MP, Sarabia L, Schön J, Gabler Ch, Einspanier R, Maliqueo M, Sir-Petermann T, Rey R \& Recabarren SE 2010 Prenatal testosterone excess alters Sertoli and germ cell number and testicular FSH receptor expression in rams. American Journal of Physiology. Endocrinology and Metabolism 299 E998-E1005. (doi:10.1152/ajpendo.00032.2010)

Rojas-García PP, Recabarren MP, Sir-Petermann T, Rey R, Palma S, Carrasco A, Perez-Marin CC, Padmanabhan V \& Recabarren SE 2013 Altered testicular development as a consequence of increase number of sertoli cell in male lambs exposed prenatally to excess testosterone. Endocrine 43 705-713. (doi:10.1007/s12020-012-9818-5)

Sakurai H, Adams BM \& Adams TE 1997 Concentration of gonadotropinreleasing hormone receptor messenger ribonucleic acid in pituitary tissue of orchidectomized sheep: effect of passive immunization against gonadotropin-releasing hormone. Journal of Animal Science 75 189-194.

Sir-Petermann T, Maliqueo M, Angel B, Lara HE, Perez-Bravo F \& Recabarren SE 2002 Maternal serum androgens in pregnant women with polycystic ovarian syndrome: possible implications in prenatal androgenization. Human Reproduction 17 2573-2579. (doi:10.1093/ humrep/17.10.2573)

Skakkebaek NE, Rajpert-De Meyts E \& Main K 2001 Testicular dysgenesis syndrome: an increasingly common developmental disorder with environmental aspects. Human Reproduction 16 972-978. (doi:10.1093/ humrep/16.5.972)

Stanislaus D, Pinter JH, Janovick JA \& Conn PM 1998 Mechanisms mediating multiple physiological responses to gonadotropinreleasing hormone. Molecular and Cellular Endocrinology 144 1-10. (doi:10.1016/S0303-7207(98)00126-9)

Tilbrook AJ, de Kretser DM, Cummins JT \& Clarke IJ 1991 The negative feedback effects of testicular steroids are predominantly at the hypothalamus in the ram. Endocrinology 129 3080-3092. (doi:10.1210/endo129-6-3080)

Turzillo AM, Di Gregorio DB \& Nett TM 1995a Messenger ribonucleic acid for gonadotropin-releasing hormone receptor and numbers of gonadotropin-releasing hormone receptors in ovariectomized ewes after hypothalamic-pituitary disconnection and treatment with estradiol. Journal of Animal Science 73 1784-1788.

Turzillo AM, Juengel JL \& Nett TM 1995b Pulsatile gonadotropin-releasing hormone $(\mathrm{GnRH})$ increases concentrations of $\mathrm{GnRH}$ receptor messenger ribonucleic acid and numbers of $\mathrm{GnRH}$ receptors during luteolysis in the ewe. Biology of Reproduction 53 418-423. (doi:10.1095/biolreprod53. 2.418)

Vanselow J, Fürbass R, Rehbock F, Klautschek G \& Schwerin M 2004 Cattle and sheep use different promoters to direct the expression of the aromatase cytochrome P450 encoding gene, Cyp19, during pregnancy. Domestic Animal Endocrinology 27 99-114.

Veiga-Lopez A, Steckler TL, Abbott DH, Welch KB, MohanKumar PS, Phillips DJ, Refsal K \& Padmanabhan V 2011 Developmental programming: impact of excess prenatal testosterone on intrauterine fetal endocrine milieu and growth in sheep. Biology of Reproduction $\mathbf{8 4}$ 87-96. (doi:10.1095/biolreprod.110.086686)

Wheaton JE, Godfrey RW \& Plasma LH 2003 FSH, testosterone, and age at puberty in ram lambs actively immunized against an inhibin $\alpha$-subunit peptide. Theriogenology 60 933-941. (doi:10.1016/S0093-691X(03) 00104-3)

Received 10 January 2013

First decision 30 January 2013

Revised manuscript received 21 March 2013

Accepted 10 April 2013 